\title{
Structural and host rock controls on the distribution, morphology and mineralogy of speleothems in the Castañar Cave (Spain)
}

\author{
ANA M. ALONSO-ZARZA*†, ANDREA MARTÍN-PÉREZ*, \\ REBECA MARTÍN-GARCÍA*, INMA GIL-PEÑA $\ddagger$, ALFONSO MELÉNDEZ $\S$, \\ ESPERANZA MARTÍNEZ-FLORES $\uparrow$, JOHN HELLSTROM $\|$ \& \\ PEDRO MUÑOZ-BARCOף
}

*Dpto. Petrología y Geoquímica, Facultad de Ciencias, Geológicas-Instituto de Geología Económica, Universidad Complutense de Madrid-CSIC, 28040, Spain

łInstituto Geológico y Minero de España (IGME), Ríos Rosas 23, 28003 Madrid, Spain

$\S$ Dpto. Ciencias de la Tierra, Facultad de Ciencias, Universidad de Zaragoza, 50009 Zaragoza, Spain

ๆConsejería de Industria, Energía y Medio Ambiente, Junta de Extremadura, Paseo de Roma, s/n 06800, Mérida, Spain

\|School of Earth Sciences, The University of Melbourne, Victoria 3010, Australia

(Received 16 February 2010; accepted 4 May 2010; first published online 28 June 2010)

\begin{abstract}
The Castañar Cave (central western Spain) formed in mixed carbonate-siliciclastic rocks of Neoproterozoic age. The host rock is finely bedded and shows a complex network of folds and fractures, with a prevalent $\mathrm{N} 150 \mathrm{E}$ strike. This structure controlled the development and the maze pattern of the cave, as well as its main water routes. The cave formed more than $350 \mathrm{ka}$ ago as the result of both the dissolution of interbedded carbonates and weathering of siliciclastic beds, which also promoted collapse of the overlying host rock. At present it is a totally vadose hypergenic cave, but its initial development could have been phreatic. The cave's speleothems vary widely in their morphology and mineralogy. In general, massive speleothems (stalactites, stalagmites, flowstones, etc.) are associated with the main fractures of the cave and bedding planes. These discontinuities offer a fairly continuous water supply. Other branching, fibrous, mostly aragonite speleothems, commonly occur in the steeper cave walls and were produced by capillary seepage or drip water. Detailed petrographical and isotope analyses indicate that both aragonite and calcite precipitated as primary minerals in the cave waters. Primary calcite precipitated in waters of low magnesium content, whereas aragonite precipitated from magnesium-rich waters. Differences in isotope values for calcite $\left(-5.2 \%\right.$ for $\delta^{18} \mathrm{O}$ and $-9.6 \%$ for $\left.\delta^{13} \mathrm{C}\right)$ and aragonite $\left(\delta^{18} \mathrm{O}\right.$ of $-4.5 \%$ and $\delta^{13} \mathrm{C}$ of $-3.5 \%$ ) can be explained by the fact that the more unstable mineral (aragonite) tends to incorporate the heavier $\mathrm{C}$ isotope to stabilize its structure or that aragonite precipitates in heavier waters. Changes in the water supply and the chemistry and instability of aragonite caused: (1) inversion of aragonite to calcite, which led to the transformation of aragonite needles into coarse calcite mosaics, (2) micritization, which appears as films or crusts of powdery, opaque calcite, and (3) dissolution. Dolomite, huntite, magnesite and sepiolite were identified within moonmilk deposits and crusts. Moonmilk occurs as a soft, white powder deposit on different types of speleothems, but mostly on aragonite formations. Huntite and magnesite formed as primary minerals, whereas dolomite arose via the replacement of both huntite and aragonite. Owing to its variety of speleothems and location in an area of scarce karstic features, the Castañar Cave was declared a Natural Monument in 1997 and is presently the target of a protection and research programme. Although the main products formed in the cave and their processes are relatively well known, further radiometric data are needed to better constrain the timing of these processes. For example, it is difficult to understand why some aragonite speleothems around $350 \mathrm{ka}$ old have not yet given way to calcite, which indicates that the environmental setting of the cave is still not fully understood.
\end{abstract}

Keywords: Castañar Cave, structure, speleothems, aragonite, calcite, diagenesis.

\section{Introduction}

Caves formed by karst processes have for many years attracted the attention of geomorphologists, mineralogists, petrologists, and archaeologists, among other scientists. Ford \& Williams (2007) defined karst as 'comprising terrain with distinctive hydrology and landforms that arise from a combination of high rock solubility and well developed secondary (fracture) porosity'. In an earlier definition, karst is

†Author for correspondence: alonsoza@geo.ucm.es also considered as a diagenetic facies (Esteban \& Klappa, 1983). The source of water is a criterion to differentiate between hypogenic cave waters, in which water is sourced from below (Klimchouk, 2009), and hypergenic caves, such as Castañar, which are recharged from the surface. With these concepts in mind, it is clear that the formation of a karstic cave will be controlled by the solubility, permeability, hydrogeology, structure and composition of the host rock and by the climatic conditions. All this will control not only the characteristics of the cave (e.g. size, morphology, hydrology) but also the type, 
mineralogy and texture of the speleothems that form within the cave. Speleothems are mineral deposits found in caves which archive records of past climate and environmental evolution, such as changes in rainfall amount, soil activity or carbon cycle, including sequestration of $\mathrm{CO}_{2}$ (Frisia \& Borsato, 2010). In addition, speleothems can be affected by a variety of diagenetic processes (Martín-García, Alonso-Zarza \& Martín-Pérez, 2009), which also imprint their features, obliterating or adding more details to the palaeoenvironmental evolution and diagenesis.

The Castañar Cave in west-central Spain is an outstanding karst system developed in an area where surface landforms (exokarst) are scarce. This is because the host rock consists predominantly of shales and greywackes with a few interbedded iron-rich dolostones and magnesites, all of them of Neoproterozoic age. Under the surface, the Castañar Cave shows an intricate maze morphology and an unusually large variety of speleothems, whose different mineralogies, textures and geochemical signals reflect a complex relationship between host rock and cave water composition. This integrated study addresses the morphology of the cave, its speleothems, diagenetic features and an approach to the possible time of formation of the cave. We discuss major controls on cave and speleothem development. Our discussion on the diagenetic features of the speleothems questions the validity of some types of speleothems for palaeoenvironmental studies.

\section{Geological setting}

The Castañar Cave is located in the eastern Iberian Massif (west-central sector of the Iberian Peninsula) (Fig. 1) at the northern foothill of the Villuercas Range (Villuercas peak, $1601 \mathrm{~m}$ ). The climate of the area is mild continental with Mediterranean influence. Mean annual temperature in the Castañar area is about $16^{\circ} \mathrm{C}$, and annual thermal oscillation is in the order of $20^{\circ} \mathrm{C}$. Precipitation shows strong interannual and seasonal variability, with a mean annual rainfall amount of $750 \mathrm{~mm}$ mainly concentrated in winter (Ninyerola, Pons \& Roure, 2005).

From the geological perspective, the study area is located in the Central Iberian Zone of the Iberian Massif, specifically in the Ibor antiform of the Domain of Vertical Folds (Díez-Balda, Vegas \& GonzálezLodeiro, 1990). Neoproterozoic to Lower Cambrian sedimentary rocks crop out in the core of this Variscan structure (Fig. 2). These rocks can be divided into two large stratigraphic units, the Domo Extremeño Group and Ibor Group (Álvarez Nava et al. 1988), separated by an unconformity. Both units are mainly composed of shales and greywackes, but the Ibor Group includes carbonate beds close to the Neoproterozoic-Cambrian boundary. The Ordovician and Silurian siliciclastic sequence, beginning with the transgressive Armorican

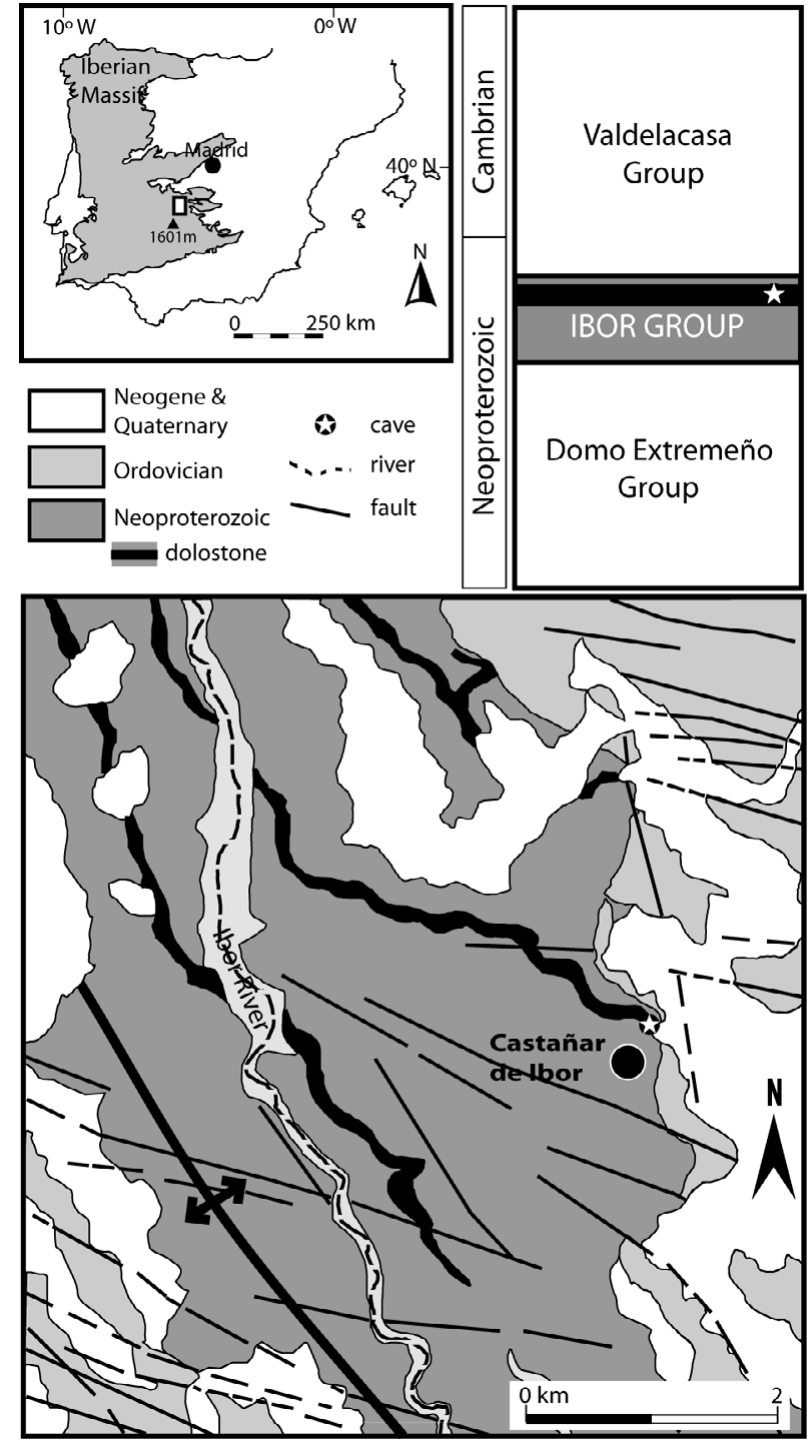

Figure 1. Location and geological and stratigraphical setting data for the Castañar Cave.

Quartzite, unconformably overlies the Ibor Group (Fig. 2).

The shallow marine uppermost Neoproterozoic sediments of the Ibor Group host the Castañar Cave. They consist of alternations of shales, sandstones and greywackes (Fig. 3a), with intercalations of decimetre- to metre-thick carbonate levels (dolostones and magnesites) (Fig. 3b). As a consequence of erosion linked to the Lower Ordovician unconformity, these carbonate levels are not present in the western limb of the Ibor antiform (Fig. 2). Main structures in this area are Variscan in age. Neoproterozoic rocks do not show complex deformation and lack significant metamorphism.

The Appalachian relief of the area is the outcome of its post-Variscan evolution. This includes uplifting and progressive exhumation of the Variscan basement, subsidence of the adjacent Tajo Basin during the Tertiary and gradual dissection by the drainage pattern. Homoclinal ridges of the Armorican Quartzites stand out over abrasion surfaces cutting across Neoproterozoic 


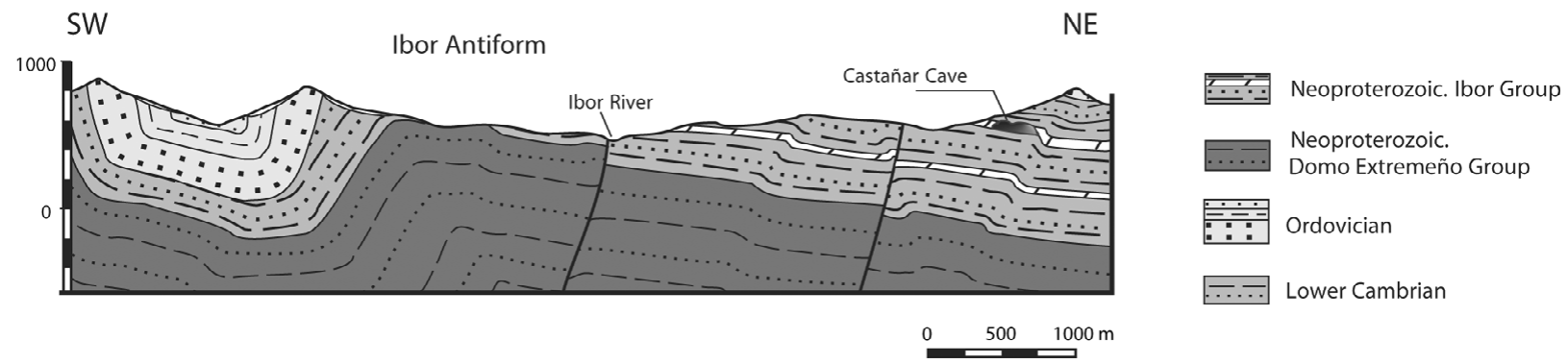

Figure 2. Geological cross-section through the Ibor Antiform. The location of the cave within the carbonates of the Ibor Group is indicated.
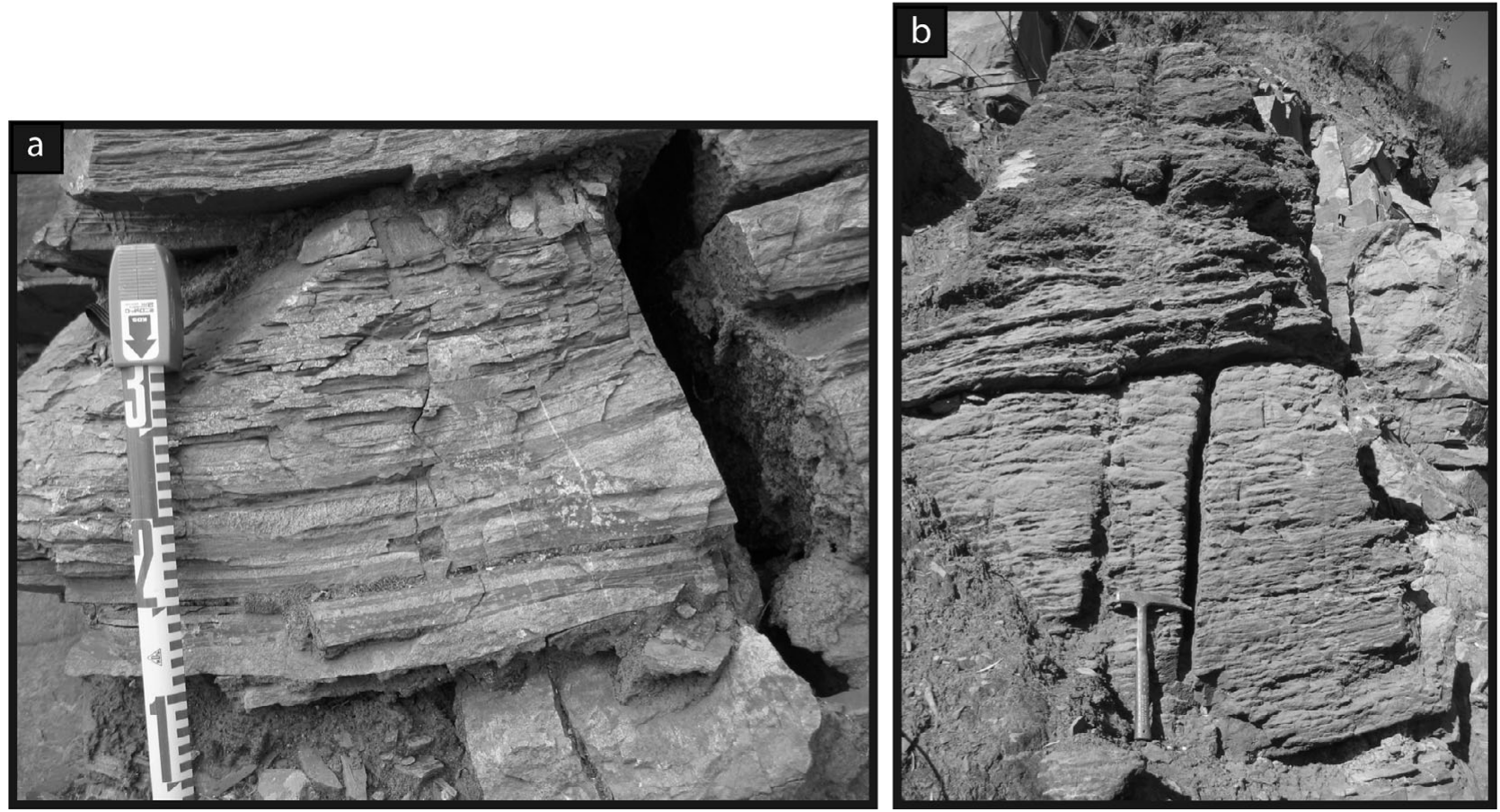

Figure 3. Neoproterozoic sediments of the Ibor Group. (a) Detritic sediments: shales and sandstones. (b) Carbonates, mainly dolostones showing no signs of magnesite. Note the thin stratification. Hammer length is $33 \mathrm{~cm}$. For a colour version of this figure, please see online appendix at http://www.cambridge.org/journals/geo.

rocks. Remains of a thin and extensive alluvial cover of quartz gravels, designated as 'Rañas' and generally attributed to the Plio-Quaternary, are locally preserved on these flat surfaces (Martínez-Flores, 2005). These alluvial deposits are located about $150 \mathrm{~m}$ above the present Ibor River. The only exokarstic forms present are solution flutes ('rillenkarren') formed on the carbonates of the Ibor Group.

The Ibor antiform is a polyharmonic fold, trending N150E. The Ordovician-Silurian sequence exhibits a general box fold geometry slightly verging to the SW. Carbonate Neoproterozoic levels reproduce this fold geometry on a decametric scale. Axial planar cleavage occurs as a penetrative structure mainly in shales.

Longitudinal and transverse fault and fracture systems are superimposed on the folding structure. Main faults are sinistral-normal faults trending ESE to E-W, conjugated with secondary NE to NNE faults. NW faults are typically associated with the hinge areas of the folds. Minor fractures reproduce similar orientations, and a N060E joint set is also present.

\section{Methodology}

Field study of the surrounding area including stratigraphical/petrological and structural work was carried out in order to get a better knowledge of the lithology and structure of the host rock. Studies within the cave include the characterization of the structure of the different rooms as well as the distribution of the different types of speleothems and their sampling. Thinsections of speleothems of different morphologies were examined by petrographic microscopy. Due to their fragility, the speleothem samples were embedded in a resin containing Epofer EX 401 and Epofer E 432 in a vacuum system. Mineralogical characterization was done by X-ray diffraction using a Philips PW$1710 \mathrm{XRD}$ system operating at $40 \mathrm{kV}$ and $30 \mathrm{~mA}$, at $2^{\circ} / \mathrm{min}$, with monochromated $\mathrm{CuK} \alpha$ radiation. XRD spectra were obtained from 2 to $66^{\circ} 2 \theta$. The different morphologies of speleothems were selected for stable isotope analyses. Only monomineral samples either of calcite or aragonite were used. The $\delta^{13} \mathrm{C}$ and $\delta^{18} \mathrm{O}$ values 


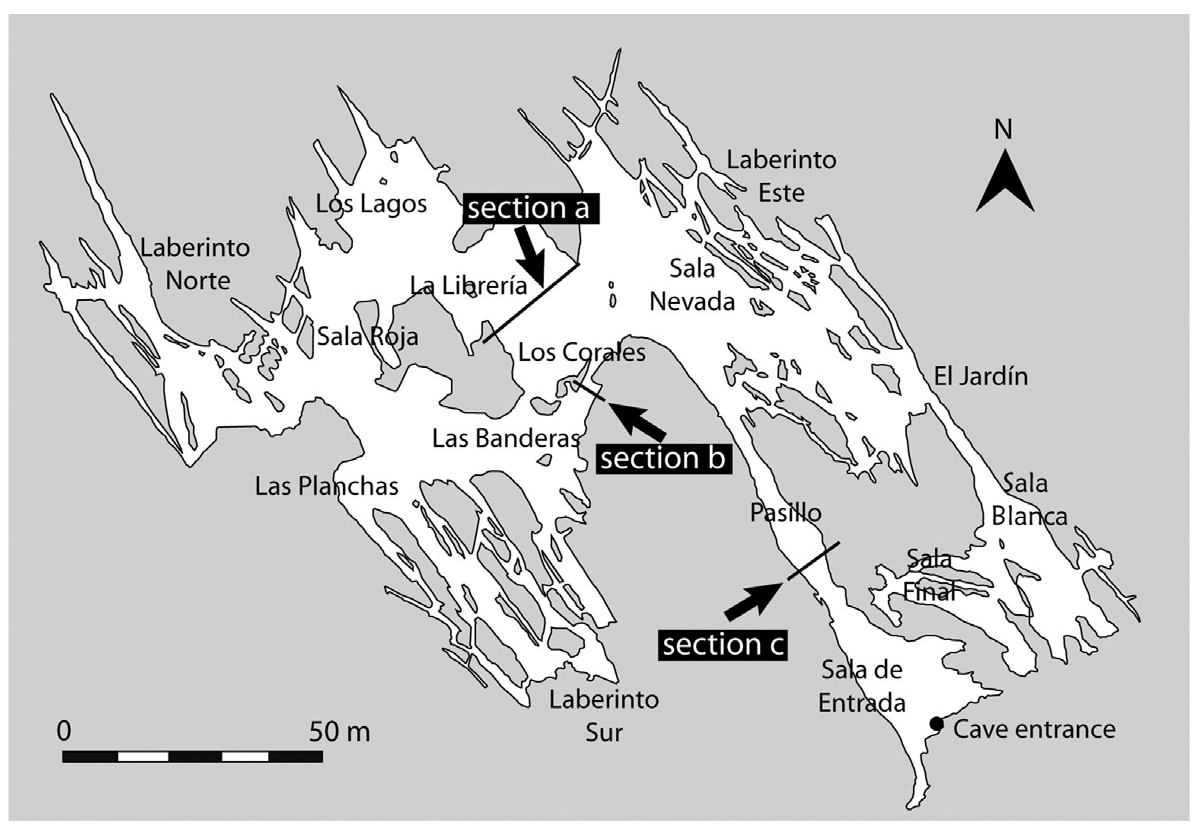

Figure 4. Map of the cave showing the names and locations of its rooms. Arrows indicate the positions of the cross-sections of the galleries shown in Figure 7.

of these powdered samples were later determined at the Stable Isotope Laboratory, Salamanca University, after reacting with $100 \%$ phosphoric acid and using a SIRA series II spectrometer supplied by VG Isotech. U-Th dating was undertaken on samples between 5 and $100 \mathrm{mg}$ cut from the speleothems by dental drill, using the procedure described by Hellstrom (2003). Only samples composed of aragonite or primary calcite were selected. Radiometric analysis used a $\mathrm{Nu}$ Instruments multi-collector ICP-MS at the School of Earth Sciences of the University of Melbourne.

\section{Castañar Cave}

The Castañar Cave consists of an intricate network of subhorizontal galleries and rooms. These main 'rooms' (Spanish: Salas) have been designated: El Jardín, Nevada, Blanca, La Librería, El Pasillo, Las Banderas, Los Lagos, Las Planchas, Los Corales, Roja and Laberintos $\mathrm{N}$ and $\mathrm{E}$ (Fig. 4). The entrance to the Cave is situated $590 \mathrm{~m}$ above sea level, whereas its lower passage (Sala Los Lagos) lies at $554 \mathrm{~m}$ a.s.l. The depth of the galleries with respect to the present topography ranges between 15 to $55 \mathrm{~m}$. In general, the galleries are narrow (a few metres wide) and about $2 \mathrm{~m}$ high, although some chambers such as La Librería are larger. The cave passages and rooms form a network that follows the N150E orientation of the host rock structure (Fig. 4) and the different chambers reproduce the geometry of the decametre-scale folds that affect the strata of Ibor Group deposits. This network or labyrinthic cave pattern together with the fine-scale stratification of greywackes, shales, dolostones and magnesites indicate clear structural and lithological control on the formation of the cave's cavities. Narrow corridors such as El Jardín gallery developed in the core of small anticlines (metre-scale). In this case, the dolostone bed has been dissolved and shales are found in the floor as fallen blocks and forming the roof of the chamber. In La Librería, the core of the anticline is also dissolved and collapsed, but since the flanks of the anticline show less dipping, this room is much wider. These maze patterns are common in caves in which water is sourced by diffuse recharge through overlying and/or underlying insoluble rocks, such as summarized by Palmer (2007). In these caves there is also a strong structural control. Bedding, fractures and cleavage planes are the main paths for water circulation, promoting weathering of the host rock and preferential alignments in speleothem growth.

The mean temperature of the cave is $16.94^{\circ} \mathrm{C}$ and it shows a yearly variation of only $0.09^{\circ}$. Mean $\mathrm{CO}_{2}$ concentration in the cave atmosphere is $3680 \mathrm{ppm}$, with an annual oscillation of $1120 \mathrm{ppm}$. Relative humidity approaches $100 \%$ (Sánchez-Moral et al. 2006). At present there is no flowing water in the cave, although there are three small pools, and drip and capillary seepage water occur throughout the cave. The mean $\mathrm{pH}$ of the cave water is 7.8 and its chemical composition is stable over the year, being rich in $\mathrm{Mg}^{2+}, \mathrm{Ca}^{2+}$ and $\mathrm{HCO}_{3}^{-}$. $\mathrm{Ca} / \mathrm{Mg}$ ratio varies through the year and depends on whether they are pool or dripping waters. For example, the ratio in the Superior lake of the Lagos room varies between 0.54 and 0.93 , whereas in dripping waters they are $>1$ in the Nevada and Librería rooms and $<1$ in El Jardín and Blanca rooms (Sánchez-Moral et al. 2006). Cave waters are close to saturation $( \pm 0.25)$ or oversaturated $(<0.25)$ in calcite, dolomite and aragonite and approaching equilibrium or slight undersaturation of magnesite, whereas they are undersaturated in huntite and hydromagnesite. 
Table 1. Mineralogy, texture and diagenetic processes of the Castañar Cave speleothems

\begin{tabular}{|c|c|c|c|c|c|}
\hline Type & Size & Mineralogy & Texture & Diagenetic processes & Figure \\
\hline \multicolumn{6}{|l|}{ Branching } \\
\hline Frostwork & $1 \mathrm{~mm}-5 \mathrm{~cm}$ & A, Dd & Fibrous-radial & Dolomitization & $5 a$ \\
\hline Anthodites & $\mathrm{cm}-\mathrm{dm}$ & $\mathrm{A}, \mathrm{Cd}$ & Fibrous & Micritization & $5 b$ \\
\hline Helictites & $\mathrm{cm}-\mathrm{dm}$ & $\mathrm{A}, \mathrm{Cd}$ & Fibrous, prismatic, mosaic & Calcitization, dissolution & $5 c$ \\
\hline \multicolumn{6}{|l|}{ Massive } \\
\hline Stalactites & $\mathrm{cm}-\mathrm{m}$ & $\mathrm{C}, \mathrm{A}, \mathrm{Cd}$ & Prismatic, fibrous, mosaic & $\begin{array}{l}\text { Calcitization, micritization, dissolution, } \\
\text { cementation }\end{array}$ & $5 d$ \\
\hline Stalagmites & $\mathrm{cm}-\mathrm{dm}$ & $\mathrm{A}, \mathrm{Cd}$ & Fibrous, mosaic & $\begin{array}{l}\text { Calcitization, micritization, dissolution, } \\
\text { cementation }\end{array}$ & $5 e$ \\
\hline Columns & $\mathrm{dm}-\mathrm{m}$ & $\mathrm{C}, \mathrm{A}, \mathrm{Cd}$ & Prismatic, fibrous, mosaic & $\begin{array}{l}\text { Calcitization, micritization, dissolution, } \\
\text { cementation }\end{array}$ & $5 f$ \\
\hline Draperies & $\mathrm{dm}-\mathrm{m}$ & $\mathrm{C}, \mathrm{A}, \mathrm{Cd}, \mathrm{Dd}$ & Prismatic, fibrous, mosaic, spheroidal & $\begin{array}{l}\text { Calcitization, micritization, dissolution, } \\
\text { cementation, dolomitization }\end{array}$ & $5 \mathrm{~g}$ \\
\hline Flowstone & $\mathrm{m}$ & $\mathrm{C}, \mathrm{A}, \mathrm{Cd}$ & Prismatic, fibrous, mosaic & $\begin{array}{l}\text { Calcitization, micritization, dissolution, } \\
\text { cementation }\end{array}$ & $5 \mathrm{~h}$ \\
\hline \multicolumn{6}{|c|}{ 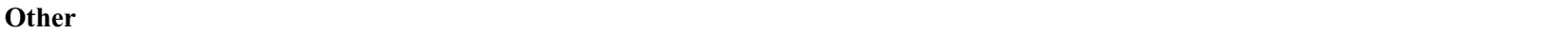 } \\
\hline Popcorn & $\mathrm{cm}-\mathrm{dm}$ & $\mathrm{A}, \mathrm{Cd}$ & Fibrous, mosaic & Cementation, calcitization & $6 a$ \\
\hline Pool & $\mathrm{m}$ & $\mathrm{A}, \mathrm{C}, \mathrm{Cd}$ & Fibrous, mosaic & Calcitization, cementation & $6 \mathrm{~b}$ \\
\hline Gours & $\mathrm{cm}$ & $\mathrm{C}$ & Prismatic, dog teeth & Cementation & $6 \mathrm{c}$ \\
\hline Rafts & $\mathrm{mm}$ & $\mathrm{C}$ & Fibrous & None & $6 \mathrm{~d}$ \\
\hline Crusts & $\mathrm{mm}-\mathrm{cm}$ & $\mathrm{A}, \mathrm{D}, \mathrm{Dd}, \mathrm{H}, \mathrm{M}, \mathrm{S}$ & Fibrous, micritic (H, M), spheroidal (D) & Dolomitization & $6 e$ \\
\hline Moonmilk & $\mathrm{mm}-\mathrm{cm}$ & $\mathrm{H}, \mathrm{M}, \mathrm{Dd}, \mathrm{S}$ & Micritic, spheroidal & Dolomitization & $6 f$ \\
\hline
\end{tabular}

$\mathrm{A}$ - aragonite; $\mathrm{C}$ - calcite; $\mathrm{D}$ - dolomite; $\mathrm{H}$ - huntite; $\mathrm{M}$ - magnesite; $\mathrm{S}$ - sepiolite; $\mathrm{d}$ - diagenetic mineral.

\section{The speleothems of Castañar Cave}

\section{5.a. Types}

The cave contains a wide variety of speleothems, which according to Hill \& Forti (1997) may be classified as: frostwork, anthodites, helictites, stalactites, stalagmites, columns, draperies, flowstones, coralloids, crusts, gours, pool deposits, rafts and moonmilk (Table 1).

Aragonite frostwork is the most common speleothem in the Castañar Cave (Fig. 5a). This acicular white speleothem grows by radiating from a common point on the walls. Sometimes frostworks are isolated but usually they cover large wall surfaces. Anthodites are aragonite speleothems that look like flowers (Fig. 5b). These form as clusters of aragonite needles or calcite after aragonite. Anthodites nucleate either directly on the host rock or on any other type of speleothem. Helictites are contorted speleothems that twist in any direction (Fig. 5c). They grow from the ceilings or walls of the cave and are mainly composed of aragonite or calcite after aragonite.

Stalactites show a conical shape (Fig. 5d). They have a central channel and are usually comprised of calcite or aragonite. Stalagmites (Fig. 5e) are formed on the floor and are fed by a thin film of water formed from the splashing droplets and do not have a central channel. They are composed of aragonite and calcite and do not necessarily correspond mineralogically to their counterpart stalactites. Columns are formed when a stalactite and stalagmite meet and grow together (Fig. 5f); they can be composed of both calcite and aragonite.

Draperies are curtain-like speleothems that hang from the ceilings and inclined walls and form along discontinuities like faults or diaclases (Fig. 5g). Draperies are comprised mainly of large calcite crystals.
Flowstones are large speleothems formed by a continuous water flux (Fig. 5h). They occur on walls and usually reach the floor and may cover previous speleothems. Their mineralogy is mostly calcite.

Aragonite coralloids (also called popcorns) are globular-like speleothems that occur on the floor, especially of fossil pools (Fig. 6a).

Gours are calcite barriers that form perpendicular to the stream flow on inclined surfaces forming cascading series of barriers and cascading series of pools (Fig. 6b).

Pools are small lakes that form on the cave floor (Fig. 6c). Pool deposits include different morphologies like bottom-nucleated aragonite fans, dog-tooth calcite crystals and raft deposits. Both dog-tooth crystals and raft deposits are only found in pools and do not form part of other speleothems. Rafts are rare in the Castañar Cave; they consist of thin planar calcite crystals that precipitate at the water-air interface. These crystals may join to form a crust on the surface of pool waters and eventually sink to the bottom (Fig. 6d).

Crusts grow over the fallen blocks of dolostones and shales (Fig. 6e). They are comprised of aragonite needles that are usually covered by dolomite, huntite and other magnesium-rich minerals.

Moonmilk (Fig. 6f) is a speleothem formed by microcrystalline aggregates of variable composition which contains variable amounts of intercrystalline water modifying its properties from plastic to powdery masses (Hill \& Forti, 1997). In this cave, moonmilk forms white plastic masses which contain between 25 to $40 \%$ water. It is formed by huntite $\mathrm{CaMg}\left(\mathrm{CO}_{3}\right)_{4}$, magnesite $\mathrm{MgCO}_{3}$ and dolomite, and in smaller amounts hydromagnesite $\mathrm{Mg}_{5}\left(\mathrm{CO}_{3}\right)_{4}(\mathrm{OH})_{2} \cdot 4\left(\mathrm{H}_{2} \mathrm{O}\right)$ and sepiolite $\left(\mathrm{Mg}_{4} \mathrm{Si}_{6} \mathrm{O}_{15}(\mathrm{OH})_{2} \cdot 6\left(\mathrm{H}_{2} \mathrm{O}\right)\right)$. No calcite has been found within the moonmilk. Aragonite can be present in moonmilk deposits because these very often form on fibrous aragonite speleothems. 

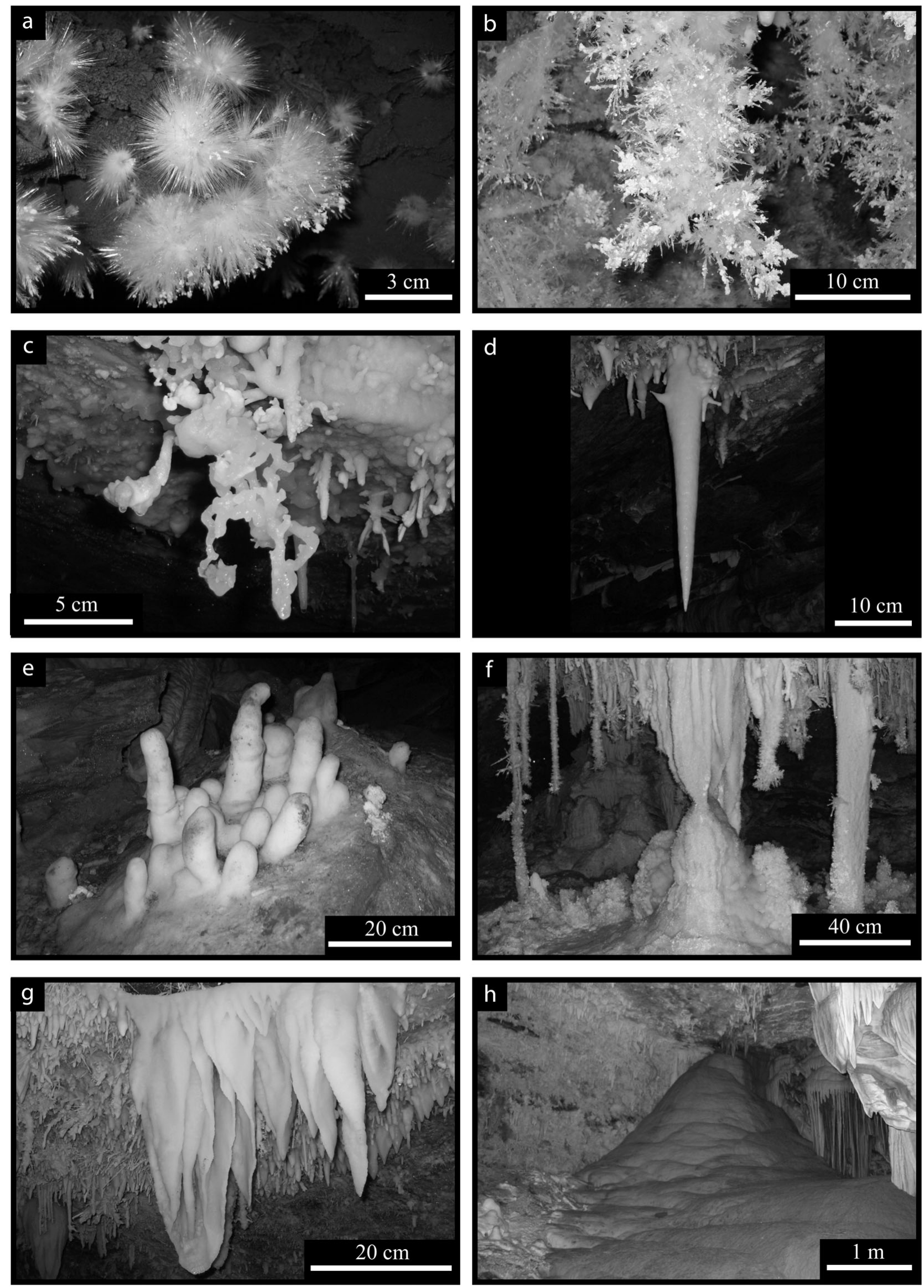

Figure 5. Speleothems of the Castañar cave: (a) frostwork; (b) anthodite; (c) helictite; (d) stalactite; (e) stalagmites; (f) group of speleothems including stalactites, stalagmites, draperies and columns (right); (g) draperies; (h) flowstone. For a colour version of this figure, please see online appendix at http://www.cambridge.org/journals/geo. 

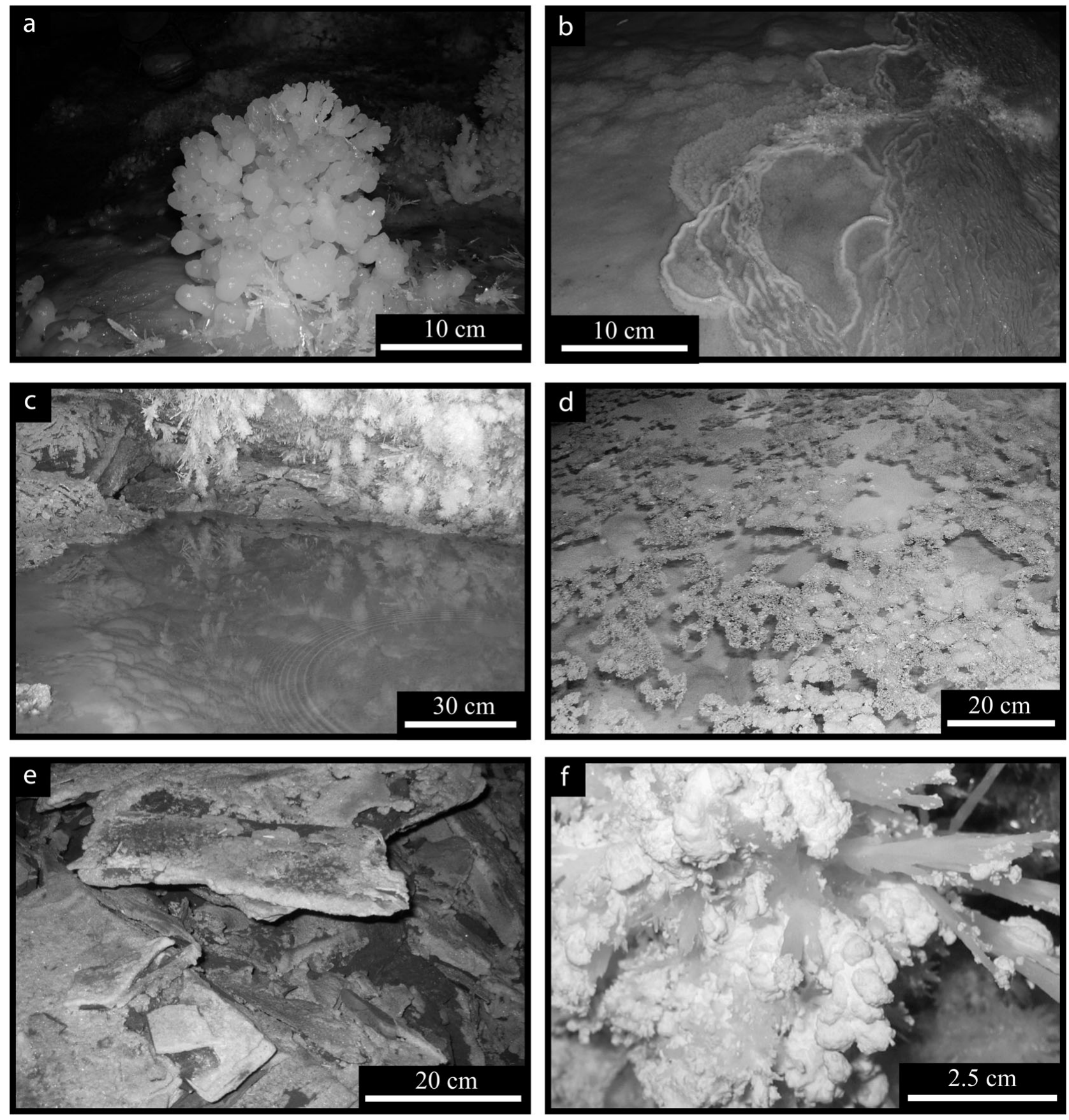

Figure 6. Speleothems of the Castañar cave (cont.): (a) coralloid; (b) gour; (c) pool; (d) rafts; (e) crusts; (f) moonmilk. For a colour version of this figure, please see online appendix at http://www.cambridge.org/journals/geo.

\section{5.b. Spatial distribution}

The speleothems in the Castañar Cave can be grouped into branching, massive and other (Table 1). The distribution of these types of speleothem is related directly to the morphology of the area where they form, the host rock structure and the amount of available water.

In general, massive speleothems (stalactites, draperies, flowstones, etc.) are associated with the two main fracture systems (N150E and N035E) and the bedding planes of the host rock striking N150, 20-70 dipping toward SE or NW, depending on the limb. Through these discontinuities in the rock, water infiltrates to form the larger speleothems such as those of $\mathrm{La}$ Librería (Fig. 7a).

Branching and fibrous speleothems (helictites, anthodites, etc.) form directly from the host rock or red clays. The most delicate and fibrous speleothems nucleate directly from the red clays, while the larger branching speleothems grow directly on the host rock or on massive speleothems (Fig. 7b). Both fibrous and branching types mainly occur on the eastern walls of the rooms (Fig. 7a-c), which usually correspond to the more steep limbs of the folds found within the cave (Fig. 7c). A detailed description and characterization 

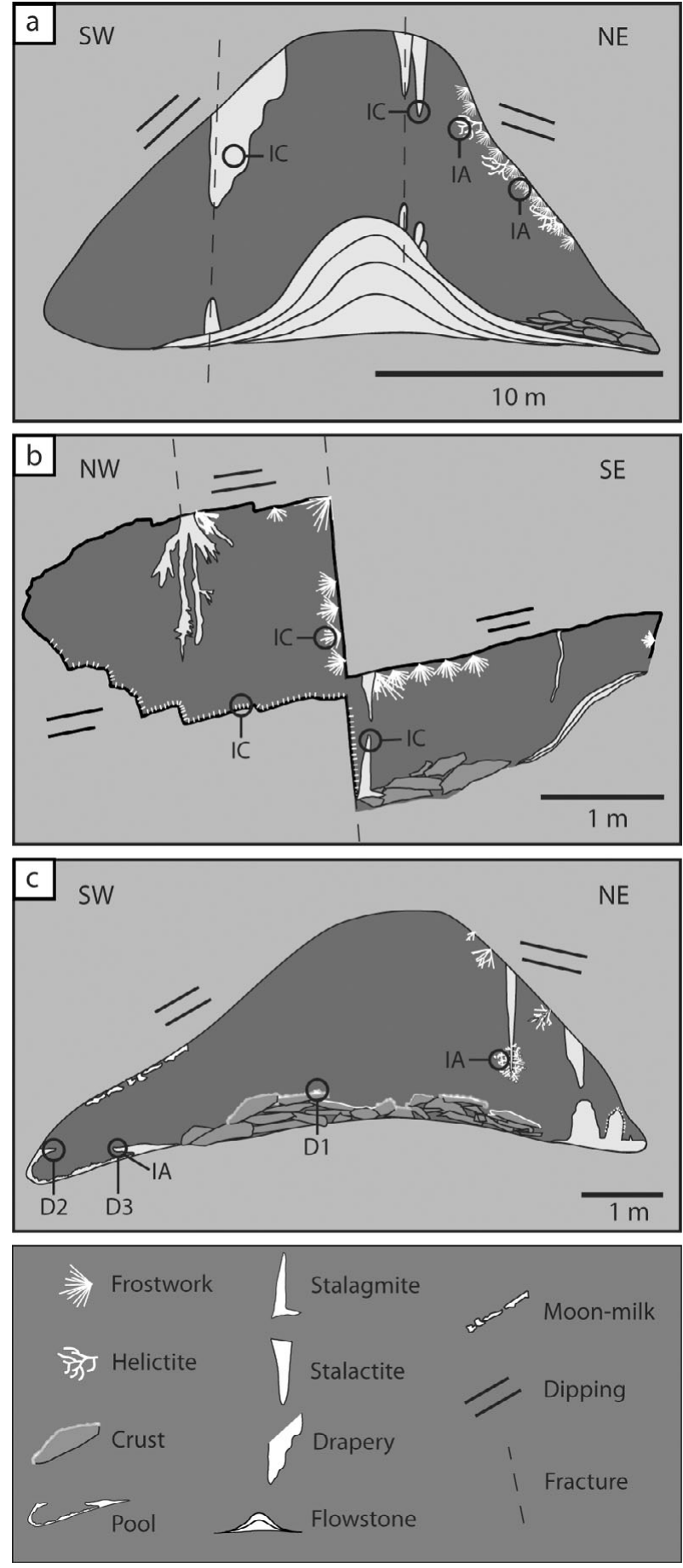

Figure 7. Cross-section sketches of (a) La Librería, (b) Los Corales and (c) El Pasillo. Note that branching and fibrous speleothems form on the steeper walls. Location of the crosssections are indicated in the map in Figure 4. The position of the samples taken for analyses is also indicated. IA - isotopes from aragonite samples, IC - isotopes from calcite samples; D1, D2 and D3 - samples used for dating.

of similar speleothems was carried out by Cabrol \& Mangin (2000) in the Grotte de Clamouse in France. These speleothems are commonly formed by aragonite.

Moonmilk develops over any other speleothems and crusts (Fig. 7c). Usually the softer and wetter moonmilk appears over the branching speleothems, but moonmilk can appear on any type of speleothem.

\section{5.c. Petrography}

The speleothems of the Castañar Cave are mainly formed of aragonite, low Mg calcite (LMC) or both, but no high Mg calcite (HMC) has been found. Moonmilk is formed by magnesium carbonates, such as dolomite, huntite and magnesite (Table 1). This is an interesting peculiar feature of the Castañar Cave, since $95 \%$ of the cave minerals of the world are calcite and aragonite (Onac, 2005).

Aragonite appears as acicular crystals with a length to width ratio $\geq 6: 1$. Both macro- and microscopically, these crystals are shiny and transparent; under the microscope they are arranged as fans growing out from a common point (Fig. 8a), causing splitting, which is very common in aragonite crystals (Self \& Hill, 2003). The fans cross each other forming different types of speleothems such as soda straws, stalactites, anthodites or crusts. Although in most caves aragonite speleothems are scarcer than their calcite counterparts, they have been commonly described in caves whose host rocks are dolostones, such as the Grotte de Clamouse in France (Cabrol \& Coudray, 1982). Aragonite is also the dominant mineral in the Ochtiná Aragonite Cave in Slovakia (Bosák et al. 2002), whose host rocks are limestones altered metasomatically to ankerites/siderites.

In some speleothems, calcite is difficult to differentiate from aragonite, even though calcite is less bright and is often brownish in colour. Under the microscope, calcite speleothems consist of palisade calcite crystals $5 \mathrm{~mm}$ to $1 \mathrm{~cm}$ long, and $0.5 \mathrm{~mm}$ wide featuring undulating extinction (Fig. 8b) or of equant mosaics of small calcite crystals 0.1 to $1 \mathrm{~mm}$ wide. Primary calcite is found in stalactites, stalagmites, flowstones, draperies, gours and rafts.

Both calcite and aragonite are considerably altered by diagenetic processes that have overprinted their primary features including mineralogy, texture and chemical composition. Aragonite fans easily transform to a mosaic of either equant or palisadic calcite, which may contain mineralogical or textural relics of aragonite (Martín-García, Alonso-Zarza \& MartínPérez, 2009) (Fig. 8c). This inversion process of aragonite into its more stable polymorph, calcite, is common in caves containing aragonite, such as caves in France (Cabrol \& Coudray, 1982; Frisia et al. 2002) or Korea (Woo \& Choi, 2006). Inversion causes aragonite speleothems to look more massive and to lose their acicular texture.

Micritization affects both calcite and aragonite, whereby large crystals are transformed into smaller ones, less than $4 \mu \mathrm{m}$ across (micrite) (Fig. 8d), converting the brilliant surface of speleothems into a powder and matte surface. Micritization is easily seen on both the outer surface of the speleothems and within them as continuous bands of micrite separating the calcite or aragonite growth bands (Fig. 8e). This micrite is formed when waters undersaturated in calcite and aragonite contact the speleothems. The mechanisms 
of formation are twofold: the so-called condensationcorrosion which occurs in the presence of an aggressive condensed moisture over the rocks (Tarhule-Lips \& Ford, 1998; Auler \& Smart, 2004; Martín-García, Martín-Pérez \& Alonso-Zarza, 2010), or the outcome of partial dissolution due to the waterflux seepage over the speleothems (Martín-García, Alonso-Zarza \& Martín-Pérez, 2009). Other possible mechanisms such as bacterial degradation or HMC inversion to micrite LMC have been discarded because neither bacterial bodies nor HMC have been found within the micritized areas. These micritized bands may serve as an indicator of interruption periods of speleothem growth.

Dissolution is easily seen in the cave, both macroand microscopically (Fig. 8f). It occurs in calcite and aragonite, and affects almost all types of speleothems, although gours and flowstones show only scarce dissolution features. Dissolution seems to be an advanced stage of micritization as it commonly occurs on powdery (micritized) speleothems with many small crystals preserved at the margins of the pores.

Huntite is the dominant mineral comprising moonmilk. Under the microscope, it appears as brownblackish micritic masses (Fig. 8g) emitting bright green fluorescence under UV light. Huntite is comprised of randomly ordered flakes or platelets less than $5 \mu \mathrm{m}$ in size. Magnesite also shows a micritic texture under the microscope appearing as rhombohedral crystals of 1 to $10 \mu \mathrm{m}$.

Dolomite forms spheroids and dumbbells 50 $300 \mu \mathrm{m}$ across in a fibrous-radial pattern with concentric bands (Fig. 8h). Dolomite spheroids may be observed between aragonite crystals, coalescing to form mosaics or even replacing aragonite. Dolomite shows different shapes of the crystal subunits, varying from rounded to rhombohedral morphologies commonly associated with huntite flakes and sepiolite fibres. Sepiolite forms fibres a few microns wide and some microns long that together form films that intergrow with huntite, dolomite and magnesite.

\section{Other cave deposits}

Red clays coat important parts of the walls, floors and ceiling of the cave. Their colour contrasts with the whiteness of the speleothems. These clays are the only non-carbonate deposits, except for the sepiolite formed within the speleothems. The clays contain a variety of silicate minerals including: quartz, feldspars and clay minerals such as illite, smectite and minor amounts of kaolinite (Martín-Pérez et al. 2010). Iron oxides/hydroxides such as goethite and hematite have also been found. Their situation with respect to the speleothems is varied; in some cases they are directly coating the walls of some rooms and serve for nucleation and growth of other speleothems, but in other cases they are deposited on the speleothems. No fluvial deposits have been recognized.
Table 2. Mineralogy and stable isotopic values of the different types of speleothems

\begin{tabular}{lllr}
\hline Speleothem type & $\mathrm{M}$ & $\delta^{18} \mathrm{O}$ & \multicolumn{1}{c}{$\delta^{13} \mathrm{C}$} \\
\hline Frostwork & $\mathrm{A}$ & -3.60 & -9.63 \\
Frostwork & $\mathrm{A}$ & -4.03 & -9.32 \\
Frostwork & $\mathrm{A}$ & -4.70 & -8.50 \\
Frostwork & $\mathrm{A}$ & -4.72 & -9.12 \\
Anthodite & $\mathrm{A}$ & -4.50 & -8.00 \\
Anthodite & $\mathrm{A}$ & -4.70 & -8.30 \\
Anthodite & $\mathrm{A}$ & -4.70 & -8.70 \\
Anthodite & $\mathrm{A}$ & -4.70 & -8.70 \\
Crust & $\mathrm{A}$ & -3.62 & -9.80 \\
Crust & $\mathrm{A}$ & -4.35 & -9.36 \\
Crust & $\mathrm{A}$ & -4.35 & -10.36 \\
Crust & $\mathrm{A}$ & -4.98 & -9.84 \\
Pool deposit & $\mathrm{A}$ & -5.70 & -9.10 \\
Crust & $\mathrm{Cc}$ & -4.30 & -9.30 \\
Drapery & $\mathrm{Cc}$ & -4.80 & -9.00 \\
Anthodite & $\mathrm{Cc}$ & -5.00 & -10.20 \\
Stalagmite & $\mathrm{Cc}$ & -5.20 & -10.00 \\
Stalagmite & $\mathrm{Cc}$ & -5.20 & -8.20 \\
Stalactite & $\mathrm{Cc}$ & -5.40 & -9.20 \\
Pool deposit & $\mathrm{Cc}$ & -6.40 & -11.40 \\
\hline
\end{tabular}

\section{Isotope geochemistry}

Figure 9 and Table 2 provide the stable isotope data obtained from the aragonite and calcite speleothems. Mean calcite values are $-5.2 \%$ for $\delta^{18} \mathrm{O}$ and $-9.6 \%$ for $\delta^{13} \mathrm{C}$. Aragonite shows mean $\delta^{18} \mathrm{O}$ and $\delta^{13} \mathrm{C}$ values of $-4.5 \%$ and $-3.5 \%$, respectively. The relatively heavier values obtained for aragonite may be explained by the following: (1) when aragonite and calcite precipitate in the same waters, aragonite contains more of the heavier isotopes because the more unstable polymorph tends to include the heavier isotopes to reduce the internal energy of the mineral and make the polymorph more stable (Morse \& Mackenzie, 1990); (2) slow, constant and prolonged degassing processes also favour the incorporation of ${ }^{13} \mathrm{C}$ in the aragonite structure (Frisia et al. 2002); (3) aragonite may precipitate from waters enriched in the heavier isotopes. The lighter values of the stable isotopes of calcite with respect to aragonite from the same cave are common to other caves containing both minerals, such as the Grotte de Clamouse (Frisia et al. 2002) or Jungteogeori Cave in Korea (Woo \& Choi, 2006). The fact that some of the calcite speleothems show similar values to aragonite formations probably indicates that these calcites are neomorphic, formed after aragonite.

Among the aragonite speleothems, the lighter isotope values correspond to pool deposits and the heavier ones to frostwork growing on speleothems. This is also seen in calcites, in which the lighter values correspond to pools and the heavier ones to stalagmites. These differences may be explained by the fact that both dripping and infiltration waters are heavier than pool waters due to the possible degassing and subsequent fractionation to heavier values (Hendy, 1971). The fractionation in $\delta^{13} \mathrm{C}$ could be an indication of the degree of ventilation of the cave (Scholz, Mühlinghaus \& Mangini, 2009). 

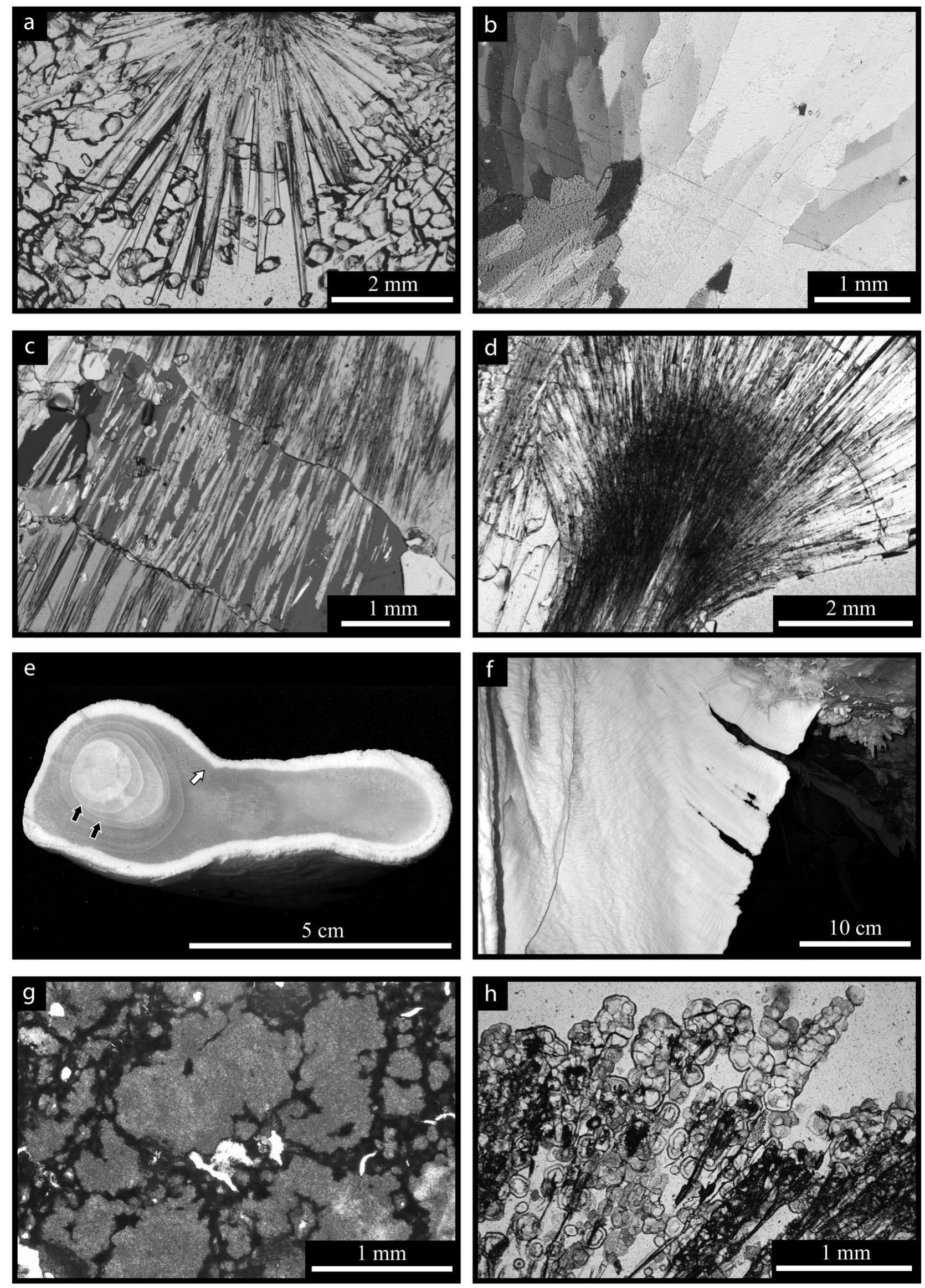

Figure 8. For caption see next page. 


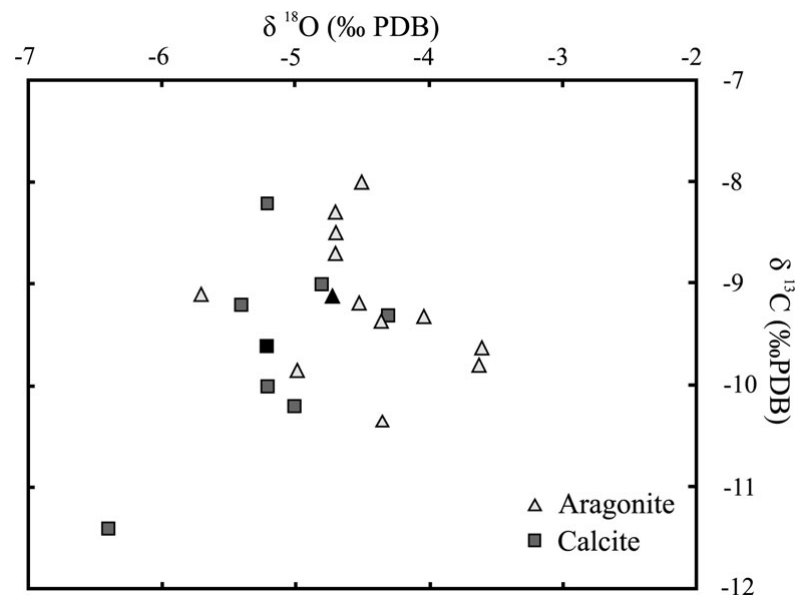

Figure 9. Stable isotope composition of some aragonite and calcite speleothems shown in Table 2 .

\section{Chronology}

The complex mineralogy and texture of the speleothems makes it difficult to obtain numerical ages from which to infer their detailed chronology. Given the diagenetic changes the speleothems have undergone and the fact they are not well laminated, a more detailed study is needed. In this paper, however, we have tried to obtain an overall picture of the main stages of speleothem formation, though not all these stages may be represented in our set of radiometric data. U-Th activity ratio and age data are shown in Table 3. Dating diagenetically altered speleothem material does not offer clear results, so only data from unaltered samples are given here. Several previous U-Th dates had to be discarded on the basis of petrographic evidence of diagenetic alteration of the material. Sample D1 is the oldest dated speleothem and corresponds to an aragonite crust deposit formed on a block of shale. This sample probably reflects the early stages of development of the cave dominated by dissolution and collapse processes. Despite its ancient age (352.9 ka), the aragonite has not transformed to calcite. Samples D2, D3a and D3b correspond to aragonite deposits that formed in the small pools of two of the rooms; none of them shows any signs of transformation. The three samples indicate a chronology approaching $70 \mathrm{ka}$ BP (Table 3). Their ages are 76.0, 71.2 and $77.7 \mathrm{ka}$, respectively (Table 3 ).

\section{Discussion}

\section{9.a. Formation of the Castañar Cave}

According to the classification scheme of Ford \& Williams (2007), the Castañar Cave is a normal meteoric water cave. The cave may be described as a perched karst system above the Ibor River, which today runs about $180 \mathrm{~m}$ below the cave entrance. The occurrence of dolostones and magnesites interbedded with highly weathered shales and greywackes indicates the water passed through non-carbonate insoluble rocks. Metre- to centimetre-scale interbedding of the different lithologies, a high degree of fracturing of both siliciclastics and carbonates, and geological structure controlled the overall development and subsequent morphology of the cavities, giving to the cave the characteristic maze pattern of caves that developed through fractures in terrains that also contain insoluble rocks (Palmer, 2007). A hypogenic origin of the cave is discarded in view of the described features. The Castañar Cave is at present a totally vadose system as is reflected by the morphology of its speleothems and by the distribution of the scarce water within the cave. Some phreatic forms that are eroded and partially incised occur, for example, in the Blanca gallery. Geological structure also controlled the distribution of the different types of speleothems, the more delicate forms occurring on the steeper walls of the cave, which correspond either to anticline limbs or fracture planes (Fig. 7). In addition, fine-grained siliciclastics from the host rock also controlled the slow circulation of capillary seepage waters in the vadose zone. This could have also promoted precipitation and dissolution in narrow fissures, as observed by Palmer \& Palmer (2003) in Mammoth Cave. In Mammoth Cave, the caprock is composed of sandstones and shales, preventing the replenishment of soil $\mathrm{CO}_{2}$ in the water that dissolved the limestones, so the $\mathrm{CO}_{2}$ content of the water drops to near zero and the $\mathrm{pH}$ may reach 9. This determines that carbonate saturation can be reached despite low levels of $\mathrm{CaCO}_{3}$ in the karstic waters.

The fact that the oldest dated speleothem occurs on a fallen block could indicate that collapses induced by the dissolution of carbonates and weathering of shales and greywackes, and perhaps also of the carbonates (Zupan-Hajna, 2003), played an important role in cave formation. Further, chronological data indicate active precipitation at least over the last $350 \mathrm{ka}$ and until $70 \mathrm{ka}$. These periods correspond to the lower part of the Riss Glaciation or OIS 10 and to the base of the last Würm Glaciation, which corresponds to the upper part of OIS 5 and to the lower part of OIS 4 . These chronological data, although sparse, have assigned most development of the cave's speleothems to cold periods of the Quaternary of the Iberian Peninsula (Silva et al. 2007). Nevertheless, more data are needed for a better climatic constraint of the Castañar Cave.

Figure 8. Petrography of the Castañar speleothems. (a) Micrograph of an aragonite fan. Plain-polarized light. (b) Micrograph of palisade calcite crystals. Cross-polarized light. (c) Image of the aragonite to calcite inversion process. Micrograph shows calcite crystals including acicular aragonite relics. Cross-polarized light. (d) Split aragonite crystals showing micritization. Plain-polarized light. (e) Hand sample of stalactite showing different stages of micritization. This process is easily seen on the outer surface (white arrow) but also in the inner parts (black arrows) marking growth bands of the speleothem. (f) Macroporosity in a drapery formed by dissolution. (g) Plain-polarized light micrograph of huntite micritic masses. (h) Dolomite spheroids over aragonite needles. Plain-polarized light. For a colour version of this figure, please see online appendix at http://www.cambridge.org/journals/geo. 
Table 3. U-Th activity ratio and age data for four speleothem samples

\begin{tabular}{lcccccrrr}
\hline Sample & Lab sample no., date & $\mathrm{U}\left(\mathrm{ngg}^{-1}\right)$ & $\left({ }^{230} \mathrm{Th} /{ }^{238} \mathrm{U}\right)$ & $\left({ }^{234} \mathrm{U} /{ }^{238} \mathrm{U}\right)$ & $\left({ }^{232} \mathrm{Th} /{ }^{238} \mathrm{U}\right)$ & $\left({ }^{230} \mathrm{Th} /{ }^{232} \mathrm{Th}\right)$ & Age $(\mathrm{ka})$ & $\left({ }^{234} \mathrm{U} / 238 \mathrm{U}\right) \mathrm{i}$ \\
\hline D1 & UMA02594, March 2009 & 11065 & $2.433(11)$ & $2.138(5)$ & $0.000143(01)$ & 17007 & $352.9(8.3)$ & $4.095(68)$ \\
D2 & UMA01565, March 2007 & 105 & $1.009(05)$ & $1.903(3)$ & $0.006908(64)$ & 146 & $76.0(0.8)$ & $2.121(05)$ \\
D3a & UMA01568, March 2007 & 1199 & $1.010(10)$ & $2.004(5)$ & $0.000074(03)$ & 13658 & $71.2(1.0)$ & $2.229(06)$ \\
D3b & UMA01678, July 2007 & 10281 & $1.040(05)$ & $1.938(4)$ & $0.000041(02)$ & 25446 & $77.7(0.6)$ & $2.169(05)$ \\
\hline
\end{tabular}

Samples analysed using the procedure of Hellstrom (2003). The numbers in round brackets are fully propagated $95 \%$ uncertainties taking into account long-term reproducibility of powdered standard materials. $\left({ }^{230} \mathrm{Th} /{ }^{238} \mathrm{U}\right)$ and $\left({ }^{234} \mathrm{U} /{ }^{238} \mathrm{U}\right)$ are determined using a a ${ }^{229} \mathrm{Th}-{ }^{233} \mathrm{U}$ mixed spike calibrated against a Harwell uraninite (HU-1) solution. Age is calculated assuming an initial ${ }^{230} \mathrm{Th} /{ }^{232} \mathrm{Th}$ activity ratio of $1.5 \pm$ 1.5 using equation 1 of Hellstrom (2006), although the effect of initial ${ }^{230} \mathrm{Th}$ is negligible in this case. $\left({ }^{234} \mathrm{U} /{ }^{238} \mathrm{U}\right) \mathrm{i}$ is calculated using $\left({ }^{234} \mathrm{U} /{ }^{238} \mathrm{U}\right)$ and the corrected age.

\section{9.b. Cave deposits}

The broad variety of textures and mineralogy of the Castañar Cave speleothems indicates different processes and controls on their formation. To our knowledge, besides this cave and the already mentioned Grotte de Clamouse (Frisia et al. 2002), very few others contain such a variety of speleothems, including the Soreq Cave in Israel (Bar-Matthews, Matthews \& Ayalon, 1991). The first aspect to be considered is why both aragonite and calcite are precipitated as primary minerals in the same cave. Maltsev (in Self \& Hill, 2003) describes speleothems in which calcite precipitated first and was followed by aragonite and hydromagnesite, because the precipitation of calcite caused an enrichment of $\mathrm{Mg}$ that favoured the precipitation of aragonite, and later on after increasing evaporation, hydromagnesite precipitated. The amount of $\mathrm{Mg}$ in the water seems to be crucial for determining the mineralogy and texture of carbonate cements (Folk, 1974). In addition, the rate of $\mathrm{CO}_{3}^{=}$supply is also an important factor (Given \& Wilkinson, 1985). Low $\mathrm{Mg}$ calcite formation is favoured under conditions of relatively lower $\mathrm{pH}$ and low concentration of $\mathrm{Mg}$ in solution. This is due to the inhibiting effect of magnesium on calcite precipitation that leads to the acicular habits commonly shown by aragonite (Bathurst, 1976). Recent experimental work (De Choudens-Sánchez \& González, 2009) shows how these two factors interact. Hence, in the presence of magnesium, it seems that LMC can only precipitate if the solution is sufficiently oversaturated to avoid the poisoning effect of magnesium. Thus, if the magnesium concentration in the water is low, LMC precipitation is always favoured, but at higher magnesium concentrations, LMC will only precipitate if the solution is highly oversaturated. In Mg-rich waters such as those of Castañar Cave, even if the solution is more saturated with respect to LMC, aragonite will precipitate out in most cases. The transformation of one polymorph to another in the presence of fluid takes place by the dissolution of the metastable phase followed by the precipitation of the stable one in a thin film solution (from 100 angstroms to 1 micron) (Perdikouri et al. 2008). This inversion occurs at the microscale when waters are understurated in aragonite and saturated in LMC. This process seems to occur very commonly in caves, as described by Hill \& Forti (1997), and may reflect changes in the composition and alkalinity of the infiltration water.

In the Ochtiná Aragonite Cave in Slovakia, Bosák et al. (2002) observed that high concentrations of $\mathrm{Mg}$, $\mathrm{Fe}$ and $\mathrm{Mn}$ ions in the cave's waters, accompanied by a closed and partly flooded environment of the cave whose walls are coated with Fe-rich wet ochres, also favour aragonite precipitation. This is because the ochres preserve the cave's humidity through capillary action or favouring slow percolation of the water on moist sediments. This could explain why in the Slovakian cave aragonite nucleates preferably in the ochres and, in the Castañar Cave, this occurs in the red clays coating its walls.

Isotope data have revealed aragonite and calcite precipitation from waters similar to the present cave waters (Sánchez-Moral et al. 2006). Differences can be mainly explained by the different kinetics of both minerals (Morse \& Mackenzie, 1990) and are not likely to be the result of enrichment with heavier isotopes after the initial precipitation of calcite. Most probably, as seen at present, aragonite and calcite nucleate and grow at the same time, but in different settings within the cave. Thus, a more continuous water supply in pools and some stalactites promoted calcite nucleation, whereas seepage and drip water provided a more favourable environment for aragonite, which forms more delicate speleothems. This is common in many other caves containing aragonite and calcite (Frisia et al. 2002), or in the Brujas Cave in Argentina (Sancho et al. 2004) where calcite coralloids and popcorns are associated with seepage processes under a very low flow regime or variable discharge. On the contrary, massive speleothems are commonly composed of calcite and require a more continuous water supply (Frisia et al. 2002). Changes in the amount of water supply and its composition (presently observed in the cave) can cause changes in the primary mineral that is precipitated (Railsback et al. 1994), but also the transformation of both primary aragonite and calcite. Aragonite to calcite inversion, micritization and dissolution occurred under conditions of a gradual drop in the saturation degree. Inversion occurs in waters saturated in calcite but undersaturated in aragonite. Waters just below the saturation degree with respect to calcite or aragonite cause micritization of either of the two, whereas undersaturated waters cause dissolution (Martín-García, Alonso-Zarza \& Martín-Pérez, 
2009). These processes and especially aragonite to calcite inversion modify the geochemical signals of the primary aragonite; these speleothems should be used with caution for palaeoenvironmental studies (Railsback et al. 2002; Fairchild et al. 2006).

The moonmilk of the Castañar Cave has two outstanding features. The first is that it is composed mostly of magnesium-rich carbonates with some sepiolite. The other is that it bears few biogenic features (AlonsoZarza \& Martín-Pérez, 2008). This makes the Castañar moonmilk different from that generally described for calcite moonmilks, whose formation seems to be driven by microbial processes (Cañaveras et al. 2006; Blyth \& Frisia, 2008). The formation of the magnesiumrich moonmilks, containing huntite and dolomite, in Castañar is driven by magnesium-rich karstic waters. Huntite is a metastable mineral (Lippmann, 1973) that may precipitate directly from solution. It may later transform to dolomite (Alonso-Zarza \& Martín-Pérez, 2008). In this transformation $\mathrm{Mg}$ is released to the residual water, favouring sepiolite precipitation. After replacing huntite, dolomite may also replace aragonite, as commonly recognized within the Castañar Cave.

Red clays formed by weathering or infiltrated from the soils, enter and move within the cave, coating mostly their walls, floors and ceiling, but also the speleothems. Although in Castañar Cave most of the red clays come from the weathering of siliciclastic rocks, some contribution from the weathering of the carbonates is also possible, as described by ZupanHajna (2003), from a number of caves in Slovenia. This is demonstrated by the presence of goethite and hematite, which are part of the insoluble residue of the dissolution of the magnesites and iron-rich dolostones.

\section{Conclusions}

The Castañar Cave and its speleothems are an archive of a set of processes of invaluable scientific and touristic interest. The composition and structure of the host rock and the fact that the cave is a relatively stable low energy system have determined the formation and preservation of an exceptional variety of speleothems. The cave formed at least $350 \mathrm{ka}$ ago and is the product of the dissolution of carbonate and the weathering of siliciclastic beds, both of which favoured collapse processes. The maze pattern of the cave is the result of the structural control on their formation and of the presence of non-soluble rocks interbedded with the carbonates. Although the maze pattern may reveal that phreatic conditions prevailed in the early times of the cave formation, now the cave is a vadose system totally fed by waters from above (meteoric waters), configuring a hypergenic cave.

The distribution, morphology and mineralogy of the different types of speleothems are controlled by the geometry of the cave, the water flow rates and its chemical composition, with the more delicate forms located on steeper walls in which the water supply is minimal and larger forms associated with fractures and large anticlines.

Primary aragonite and calcite formed concurrently, but in different positions within the cave. Thus, areas with a more continuous water supply were more prone to calcite formation, whereas aragonite formed from capillary seepage waters and dripping waters, and was also promoted by the presence of wet red clays. The degree of saturation and magnesium content of the waters determine whether calcite or aragonite is precipitated. In magnesium-rich water, it seems that calcite can only precipitate if the solution is sufficiently oversaturated to overcome the magnesium poisoning effect. Thus, primary calcite will form in waters with low magnesium contents or in highly oversaturated magnesium-rich waters. In the remaining situations aragonite forms. Aragonite, due to its instability was transformed to calcite (inversion), and both aragonite and calcite underwent further significant diagenetic processes such as micritization and dissolution. All these processes relate to changes in the supply and chemistry of the cave waters. These processes changed the mineralogy, texture and geochemistry of the primary minerals and gave rise to secondary minerals, whose geochemical signatures must be used with caution for palaeoenvironmental studies, including radiometric dating.

Apart from LMC and aragonite, the Castañar Cave contains a variety of magnesium-rich carbonates, such as huntite, dolomite, magnesite, and the clay mineral sepiolite. All of these minerals occur within moonmilk deposits and crusts. Their formation is the consequence of the high magnesium levels of the cave waters, and they may be primary minerals such as huntite or magnesite, or conversely, dolomite may form by the replacement of previous huntite or aragonite. The magnesium released in huntitedolomite transformation favours sepiolite formation.

The Castañar Cave is a natural laboratory for better understanding the formation and diagenetic evolution of a wide variety of speleothems. This paper provides an overview of the cave, its morphology, its speleothems and the main processes operating within them, but better chronological and palaeoclimatic constraints are needed to shed more light on the duration of the different processes. For example, it is difficult to explain why some aragonite crusts, about $350 \mathrm{ka}$ old, have not undergone any of the transformations described and are so neatly preserved. The Junta de Extremadura is making a special effort to conserve this Natural Monument in the best state possible and make visitors understand the processes involved in its formation and why it should be carefully preserved.

Acknowledgements. This work received financial support from the Junta de Extremadura through FEOGA314 ORIENTACION-FEDER funds, Projects CGL-2008-05584C02-02 from the MCINN and UCM-910404 from UCMCAM. A. Blázquez is thanked for helpful discussion during field work. A. Košir and F. Gutiérrez-Santolalla provided helpful discussions on cave formation processes. C. Hill 
and an anonymous reviewer notably contributed to the improvement of the paper. A. Burton carefully reviewed the text style. R. M.-G. was supported by a JAEPredoc-CSIC grant and A. M.-P. by an I3P-CSIC grant.

\section{References}

Alonso-Zarza, A. M. \& Martín-PÉreZ, A. 2008. Dolomite in caves: recent dolomite formation in oxic, nonsulfate environments. Castañar Cave, Spain. Sedimentary Geology 205, 160-4.

Álvarez Nava, H., García Casquero, J. L., Gil, A., HERnÁNDEZ URROZ, J., LORENZO, S., LÓPEZ DÍAz, F., Mira, M., Monteserín, V., Nozal, F., PARdo, M. V., Picart, J., Robles, R., Santamaría, J. \& Solé, F. J. 1988. Unidades litoestratigráficas de los materiales precámbrico-cámbricos en la mitad suroriental de la Zona Centro-Ibérica. II Congreso Geológico de España 1, 19-22.

AUler, A. S. \& SMART, P. L. 2004. Rates of condensation corrosion in speleothems of semi-arid northeastern Brazil. Speleogenesis and Evolution of Karst Aquifers 2.

Bar-Matthews, M., Matthews, A. \& Ayalon, A. 1991. Environmental controls of speleothem mineralogy in a karstic dolomitic terrain, Soreq Cave, Israel. Journal of Geology 99, 189-207.

Bathurst, R. G. C. 1976. Carbonate Sediments and their Diagenesis. Amsterdam: Elsevier, 658 pp.

BLYTH, A. J. \& FRISIA, S., 2008. Molecular evidence for bacterial mediation of calcite formation in cold highaltitude caves. Geomicrobiology Journal 25, 101-11.

Bosák, P., Bella, P., Cilek, V., Ford, D. C., Hercman, H., Kadlec, J., Osborne, A. \& Pruner, P. 2002. Ochtiná aragonite cave (Slovakia): morphology, mineralogy and genesis. Geologica Carpathica 53, 399-410.

CABROL, P. \& COUdRAY, J. 1982. Climatic fluctuations influence the genesis and diagenesis of carbonate speleothems in Southwestern France. National Speleological Society Bulletin 44, 112-7.

CABROL, P. \& MANGIN, A. 2000. Fleurs de Pierre. Lausanne: Delachaux et Niestlé, $191 \mathrm{pp}$.

CAÑAVEras, J., CUEZVA, S., SÁNCHEZ-Moral, S., LARIO, J., LAIZ, L., GONZÁlEZ, J. \& SAIZ-JiMÉNEZ, C. 2006. On the origin of fiber calcite crystals in moonmilk deposits. Naturwissenschaften 93, 27-32.

De Choudens-SÁnchez, V. \& GonzÁlez, L. A. 2009. Calcite and aragonite precipitation under controlled instantaneous supersaturation: elucidating the role of $\mathrm{CaCO}_{3}$ saturation state and $\mathrm{Mg} / \mathrm{Ca}$ ratio on calcium carbonate polymorphism. Journal of Sedimentary Research 79, 363-76.

Díez-Balda, M. A., Vegas, R. \& GonzÁlez-Lodeiro, F. 1990. Central-Iberian Zone. Autochthonous sequences: structure. In Pre-Mesozoic Geology of Iberia (eds R. D. Dallmeyer \& E. Martínez-García), pp. 172-88. Berlin: Springer-Verlag.

Esteban, M. \& KLAPPA, C. F. 1983. Subaerial exposure environments. In Carbonate Depositional Environments (eds P. A. Scholle, D. G. Bebout \& C. H. Moore), pp. 1-96. Tulsa, Oklahoma: American Association of Petroleum Geologists Memoir.

Fairchild, I. J., Smith, C. L., BAKer, A., Fuller, L., Spotl, C., MatTey, D., MCDERMOTt, F. \& E.I.M.F. (EDINBURGH ION MICROPROBE FACILITY). 2006. Modification and preservation of environmental signals in speleothems. Earth-Science Reviews 75, 105-53.
FOLK, R. L. 1974. The natural history of crystalline calcium carbonate: effect of magnesium content and salinity. Journal of Sedimentary Petrology 44, 40-53.

ForD, D. C. \& Williams, P. W. 2007. Karst Hydrogeology and Geomorphology. Chichester, England: Wiley, $562 \mathrm{pp}$.

FrisiA, S. \& BorSATO, A. 2010. Karst. In Carbonates in Continental Settings: Facies, environments and processes (eds A. M. Alonso Zarza \& L. H. Tanner), pp. 269-318. Amsterdam: Elsevier.

Frisia, S., Borsato, A., FAirchild, I. J., McDermotT, F. \& SELMO, E. M. 2002. Aragonite-calcite relationships in speleothems (Grotte de Clamouse, France): environment, fabrics and carbonate geochemistry. Journal of Sedimentary Research 72, 687-99.

Given, R. K. \& WiLKINSON, B. H. 1985. Kinetic control of morphology, composition, and mineralogy of abiotic sedimentary carbonates. Journal of Sedimentary Research 55, 109-19.

Hellstrom, J. C. 2003. Rapid and accurate U/Th dating using parallel ion-counting multicollector ICP-MS. Journal of Analytical Atomic Spectrometry 18, 134651.

HeLlstrom, J. 2006. U-Th dating of speleothems with high initial ${ }^{230}$ Th using stratigraphical constraint. Quaternary Geochronology 1, 289-95.

HENDY, C. H. 1971. The isotopic geochemistry of speleothems - I. The calculation of the effects of different modes of formation on the isotopic composition of speleothems and their applicability as palaeoclimatic indicators. Geochimica et Cosmochimica Acta 35, 80124.

HiLl, C. A. \& ForTI, P. 1997. Cave Minerals of the World. Huntsville, AL: National Speleological Society, 463 pp.

KLIMCHOUK, A. 2009. Morphogenesis of hypogenic caves. Geomorphology 106, 100-17.

LippmanN, F. 1973. Sedimentary Carbonate Minerals. New York: Springer-Verlag, $228 \mathrm{pp}$.

Martín-GARcíA, R., AlONSO-ZARZA, A. M. \& MARTínPÉrEZ, A. 2009. Loss of primary texture and geochemical signatures in speleothems due to diagenesis: evidences from Castañar Cave, Spain. Sedimentary Geology 221, 141-9.

MARTíN-GARCÍA, R., MARTÍN-PÉREZ, A. \& AlONSO-ZARZA, A. M. 2010. The petrological studies as a tool to evaluate the degradation of speleothems in touristic caves. Castañar de Ibor Cave, Cáceres, Spain. In Advances in Research in Karst Media (eds B. Andreo, F. Carrasco, J. J. Durán \& J. A. LaMoreaux), pp. 509-14. Berlin: Springer-Verlag.

Martín-PÉREZ, A., MARTín-GarcíA, R., Alonso-ZarZa, A. M. \& Herrero-FernándeZ, M. J. 2010. Features and origin of red clays in Castañar Cave: a touch of colour. In Advances in Research in Karst Media (eds B. Andreo, F. Carrasco, J. J. Durán \& J. A. LaMoreaux), pp. 515-20. Berlin: Springer-Verlag.

MARTíneZ-Flores, E. 2005. Raña de Cañamero. In Patrimonio geológico en Extremadura: geodiversidad y lugares de interés geológico (eds P. Muñoz-Barco \& E. Martínez-Flores), pp. 197-203. Mérida: Dirección General de Medio Ambiente, Consejería de Agricultura y Medio Ambiente. Junta de Extremadura.

MorSE, J. W. \& MACKENZIE, F. T. 1990. Geochemistry of Sedimentary Carbonates. Amsterdam: Elsevier, 707 pp.

Ninyerola, M., Pons, X. \& Roure, J. M. 2005. Atlas Climático Digital de la Península Ibérica. Metodología y aplicaciones en bioclimatología y geobotánica. Universidad Autónoma de Barcelona, Bellaterra. 
ONAC, B. P. 2005. Minerals. In Encyclopedia of Caves (eds D. C. Culver \& W. B. White), pp. 371-8. London: Elsevier Academic Press.

Palmer, A. N. 2007. Cave Geology. Dayton, Ohio: Cave Books, $454 \mathrm{pp}$.

Palmer, A. N. \& Palmer, M. V. 2003. Geochemistry of capillary seepage in Mammoth Cave. Speleogenesis and Evolution of Karst Aquifers 1.

Perdikouri, C., Kasioptas, A., Putnis, C. W. \& Putnis, A. 2008. The effect of fluid composition on the mechanisms of the aragonite to calcite transitions. Mineralogical Magazine 72, 111-4.

Railsback, L. B., Brook, G. A., Chen, J., Kalin, R. \& FLEISHER, C. J. 1994. Environmental controls on the petrology of a late Holocene speleothem from Botswana with annual layers of aragonite and calcite. Journal of Sedimentary Research 64, 147-55.

Railsback, L. B., Dabous, A. A., Osmond, J. K. \& FLEISHER, C. J. 2002. Petrographic and geochemical screening of speleothems for U-series dating: an example from recrystallized speleothems from Wadi Sannur cavern, Egypt. Journal of Cave and Karst Studies 62, 108-16.

SÁnchez-Moral, S., Cuezva, S., LARIO, J. \& TABORDADUARTE, M. 2006. Hydrochemistry of karstic waters in a low-energy cave (Castañar de Ibor, Spain). In Karst, cambio climático y aguas subterráneas (eds J. J. Durán, B. Andreo \& F. Carrasco), pp. 339-47. Madrid: IGME.
SANChO, C., PeÑA, J. L., MikKan, R., OsÁCAR, C. \& Quinif, Y. 2004. Morphological and speleothemic development in Brujas Cave (Southern Andean Range, Argentine): palaeoenvironmental significance. Geomorphology 57, 367-84.

Scholz, D., Mühlinghaus, C. \& Mangini, A. 2009. Modelling $\delta^{13} \mathrm{C}$ and $\delta^{18} \mathrm{O}$ in the solution layer on stalagmite surfaces. Geochimica et Cosmochimica Acta 73, 2592-602.

SELF, C. A. \& HiLl, C. A. 2003. How speleothems grow: an introduction to the ontogeny of cave minerals. Journal of Cave and Karst Studies 65, 130-51.

Silva, P. G., Zazo, C., Barjadi, T., BAena, J., Lario, J. \& Rosas, A. 2007. Tabla cronoestratigráfica del Cuaternario de la Península Ibérica, AEQUA.

TARHULE-LIPS, R. F. A. \& FORD, D. C. 1998. Condensation corrosion in caves of Cayman Brac and Isla de Mona. Journal of Cave and Karst Studies 60, 84-95.

Woo, K. S. \& CHOI, D. W. 2006. Calcitization of aragonite speleothems in limestone caves in Korea: diagenetic process in a semiclosed system. In Perspectives on Karst Geomorphology, Hydrology and Geochemistry A tribute volume to Derek C. Ford and William B. White (eds R. S. Harmon \& C. Wicks), pp. 297-30. Geological Society of America, Special Paper no. 404.

ZuPAN-HAJNA, N. 2003. Incomplete Dissolution: Weathering of Cave Walls and the Production, Transport and Deposition of Carbonate Fines. Ljubljana: Karst Research Institute ZRC SAZU, 167 pp. 